\title{
An improved extraction method reveals varied DNA content in different parts of the shells of Pacific oysters
}

\author{
Qiuyun Jiang ${ }^{1,2, a}$, Lei Wei ${ }^{1, a}$, Chaowei Gai ${ }^{1}$, Wenchao Yu ${ }^{1}$, Cheng $\mathrm{He}^{1}$, Man Chen ${ }^{1}$, Zhen Zhang ${ }^{1}$, \\ Hongce Song ${ }^{1}$, Xiaona Wang ${ }^{1}$, and Xiaotong Wang ${ }^{1,2, *}$ \\ ${ }^{1}$ School of Agriculture, Ludong University, Yantai 264025, PR China \\ ${ }^{2}$ National Demonstration Center for Experimental Fisheries Science Education, Shanghai Ocean University, Shanghai 201306, PR China
}

Received 26 October 2018 / Accepted 25 January 2019

Handling Editor: Ryan Carnegie

\begin{abstract}
The DNA in the shell of Crassostrea gigas could have important roles in the shell biomineralization. However, limited by the low efficiency of existing extraction methods, studies investigating the DNA in shells are lacking. In this study, the shell DNA of $C$. gigas was extracted using the organic solvent extraction (OSE) and guanidine lysis buffer (GLB) methods; the efficiency and quality of these two methods were compared. The sequences of a mitochondrial gene (cytochrome c oxidase subunit I, COI) and a nuclear gene (28S rRNA) of $C$. gigas were analyzed to verify the origin of the extracted shell DNA. Finally, the DNA contents of the ventral edge, middle part, and dorsal edge of $C$. gigas shells were compared. The results showed that OSE had a higher DNA extraction efficiency than GLB; the oyster shell DNA was homologous to the oyster genome; the DNA content was higher in the ventral edge than in the middle part or in the dorsal edge of the $C$. gigas shell. This study not only reports an improved extraction method for the mollusk shell DNA, but also revealed that the DNA in the oyster shell originates from the oyster body and that the DNA content in different parts of the $C$. gigas shell showed obvious variance. These results provide supporting evidence for the hypothesis that oyster cells participate in shell formation, and also afford a nondestructive method for oyster genetic identification, which can promote the application of molecular biology technology in oyster breeding. In addition, a shell growth pattern of 'Under Old \& Exceeding Old' was also proposed.
\end{abstract}

Keywords: Pacific oyster / shell DNA / in vivo sampling / DNA extraction / shell growth

\section{Introduction}

Mollusk shells are formed by biomineralization and protect the soft body within (Oberlander, 1984). Biomineralization results from interactions between organic and inorganic molecules and the deposition of the calcium carbonate $\left(\mathrm{CaCO}_{3}\right)$ crystal shell (Mann et al., 1993). Mollusk shells are formed via a complex, ordered biological process, which is regulated by various organic molecules (Samata, 1991; Wang et al., 2013). Moreover, the regular higher-order crystal structure of the mollusk shell has more specialized characteristics compared with ordinary $\mathrm{CaCO}_{3}$ crystals, for example, its strength is 3000 times that of single $\mathrm{CaCO}_{3}$ crystals (Lowenstam, 1981). Studies of the organic matrix of mollusk shells have shed light on biomineralization in mollusks

\footnotetext{
*Corresponding author: wangxiaotong999@163.com

${ }^{\mathrm{a}}$ These authors contributed equally to this work.
}

(He and Mai, 1999). Crenshaw et al. used a mild decalcifying agent (ethylenediaminetetraacetic acid, EDTA) to decalcify shells of Merceria mercenaria, partially retaining organic macromolecules of the shell (Crenshaw, 1972), revealing, for the first time, the organic matrix of a mollusk shell. Further research suggested that the content of the organic matrix in the mollusk shell was $<5 \%$ of its total mass (Currey, 1977; Okumura and Gennes, 2001). In addition, the organic matrix of shells of different species or even among individuals of the same species vary in different environments or growth periods (Mann et al., 1991). For instance, different types of peptide have been isolated and identified from the calcite and aragonite layers of the nautilus shell (Weiner and Hood, 1975). Also, some researchers extracted DNA from the ancient mollusc shells (Der Sarkissian et al., 2017), giving the possibility to extract DNA from shells of dead oysters.

There are a variety of molecules in the organic matrix of mollusk shells, including proteins, polysaccharides, and a small amount of DNA (Wang et al., 2012). However, because 


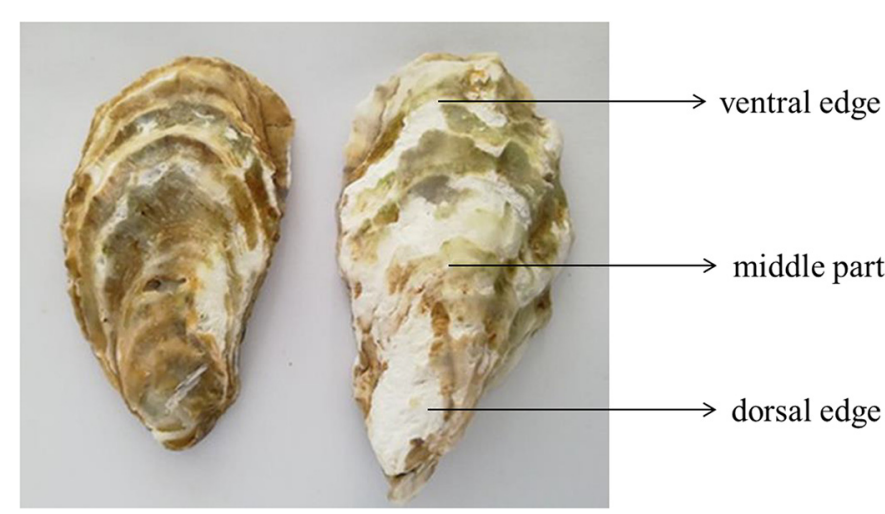

Fig. 1. Sampling sites of the dorsal, middle, and ventral edges of C. gigas shells.

of inefficient shell DNA extract methods, research has mainly focused on the protein and polysaccharide contents of the shells (Wang et al., 2014). Therefore, there has been a need for a more effective shell DNA extraction method for future functional analyses of mollusk shell DNA.

The current study focused on the shell of the model organism Crassostrea gigas. We investigated the effectiveness of two different DNA extraction methods and determined the origin of shell DNA by sequence alignment. In addition, the DNA contents of the dorsal, middle, and ventral edges of $C$. gigas shells were compared, and a shell growth pattern was proposed. Our study provides a noninvasive means of DNA extraction, which could be used to overcome the mortality associated with anesthesia sampling of DNA from the soft body of the mollusks (Suquet et al., 2009). Thus, our proposed method will also be useful for future molecular breeding studies of this economically important group of organisms.

\section{Materials and methods}

\subsection{Animal preparation}

A total of 52 adult oysters (shell height $80-100 \mathrm{~mm}$ ) were collected from an aquafarm in Yantai, Shandong Province, China. The oysters were then acclimated in an aquarium tank $(80 \times 40 \times 40 \mathrm{~cm}$, length $\times$ width $\times$ height $)$ supplied with filtered seawater at ambient temperature $\left(16 \pm 1{ }^{\circ} \mathrm{C}\right)$ and salinity (30\%) for 2 weeks before the start of the experiment. During the acclimation period, oysters were fed with microalgae Isochrysis galbana $\left(5.0 \times 10^{5} \mathrm{cell} / \mathrm{mL}\right)$ daily. After feeding, the seawater was fully renewed daily.

After acclimation, 12 adults were randomly selected for shell DNA extraction, and the remaining 40 adults were used for mortality analysis.

Of the 12 oysters for DNA extraction, six were used in the group of improved organic solvent extraction method and the other six in the group of guanidine lysis buffer method. Each shell was sampled from ventral, middle, and dorsal locations, respectively. When sampling the ventral and dorsal locations, take $1 \mathrm{~cm}$ from the edge position to the middle position. When sampling the middle location, take $0.5 \mathrm{~cm}$ on both sides of the midline of the shell.

\subsection{Shell sheared off and mortality analysis}

The shells of the oysters were cleaned thoroughly, and the periostraca were removed from the shells using abrasive paper to prevent contamination with DNA from other organisms. The ventral, middle, and dorsal edges of each oyster shell were selected as shown in Figure 1. The sheared-off shell pieces were cleaned with deionized water and placed in an oven for $6 \mathrm{~h}$ at $65^{\circ} \mathrm{C}$ until completely dry; the pieces of shell were then ground into powder using a pestle and mortar.

For mortality analysis, a piece of the left shell (approx. $1 \mathrm{~cm}^{2}$ and $1 \mathrm{~g}$ ) was sheared off from the ventral edge of the sheared-off shell group $(n=20)$, whereas the control group were left intact $(n=20)$. All the experimental oysters were cultured under the same conditions as detailed above. After 30 days, the mortality of the two groups was calculated based on the number of dead individuals.

\subsection{Improved organic solvent extraction method}

DNA was extracted from the oyster shells following the organic solvent extraction (OSE) method described by Wang et al. (2012). The powdered shells were transferred to $1.5-\mathrm{mL}$ EP tubes at $100 \mathrm{mg} /$ tube and $1 \mathrm{~mL}$ EDTA $(\mathrm{pH}=8.0)$ was added to each tube (adding EDTA chelated $\mathrm{Ca}^{2+}$ to remove the calcium from $C$. gigas shells is the primary modification compared with old OSE). The tubes were then shaken at $200 \mathrm{rpm}$ for $12 \mathrm{~h}$ at $37^{\circ} \mathrm{C}$ on a shaker to induce decalcification. The tubes were then centrifuged at $4000 \mathrm{rpm}$ for $15 \mathrm{~min}$. The supernatant was discarded to remove any redundant saline ions, and the sediment was washed with $100 \mu \mathrm{L}$ deionized water. Then, $600 \mu \mathrm{L}$ Tris- $\mathrm{HCl}(\mathrm{pH}=8.0)$ and $20 \mu \mathrm{L}$ proteinase $\mathrm{K}$ were added and the tube was incubated for $6 \mathrm{~h}$ at $56^{\circ} \mathrm{C}$. In the next step, $600 \mu \mathrm{L} \mathrm{PCI}$ (phenol:chloroform: isoamyl alcohol $=25: 24: 1 ; \mathrm{v} / \mathrm{v}$ ) was added to each tube. The solution was mixed and centrifuged at $12000 \mathrm{rpm}$ for $10 \mathrm{~min}$. After centrifugation, the supernatants were transferred to new $1.5-\mathrm{mL}$ EP tubes; $600 \mathrm{~mL}$ chloroform was added to each tube, which was then centrifuged at $12000 \mathrm{rpm}$ for $10 \mathrm{~min}$. The supernatants were again transferred to new EP tubes to which $600 \mathrm{~mL}$ isopropyl alcohol (precooled at $-20^{\circ} \mathrm{C}$ ) was added. After mixing and centrifugation at $12000 \mathrm{rpm}$ for another $10 \mathrm{~min}$, the supernatants were discarded. The sediments in each tube were washed twice with $50 \mu \mathrm{L} 75 \%$ ethanol (precooled at $-20^{\circ} \mathrm{C}$ ), air dried, and dissolved in $5 \mu \mathrm{L}$ TE buffer.

\subsection{Guanidine lysis buffer method}

Shell DNA extraction by guanidine lysis buffer (GLB) was performed according to the method described by Pawlowski, with minor modifications (Pawlowski, 2000). One milliliter GLB [ $4 \mathrm{~mol} / \mathrm{L}$ guanidine thiocyanate, $0.1 \mathrm{~mol} / \mathrm{L}$ Tris- $\mathrm{HCl}$ (pH 7.6), 0.2 mol/L EDTA (pH 8.0), TE buffer, TritonX-100] was mixed with $100 \mathrm{mg}$ shell powder in EP tubes, and incubated for $15 \mathrm{~min}$ at $60^{\circ} \mathrm{C}$. The tubes were then centrifuged at $8000 \mathrm{rpm}$ for $1 \mathrm{~min}$. The supernatants were transferred to new tubes to which $600 \mathrm{~mL}$ isopropyl alcohol (precooled at $-20^{\circ} \mathrm{C}$ ) was added. After mixing, the tubes were incubated for $2 \mathrm{~h}$ at $-20^{\circ} \mathrm{C}$ and centrifuged at $15000 \mathrm{rpm}$ for $15 \mathrm{~min}$. The supernatants were then discarded and the sediments in each 
Table 1. Experimental primers used in the study.

\begin{tabular}{ll}
\hline Experimental primer & $5, \rightarrow 3$, \\
\hline \multirow{2}{*}{ COI } & F: GGTAACTGGCTTATCCCT \\
& R: GCTAATACCAGCAAGGTG \\
FS rRNA & R: TAGGAGTCGGGTTGTTTGAG \\
\hline
\end{tabular}

tube were washed twice with $50 \mu \mathrm{L} 75 \%$ ethanol (precooled at $-20^{\circ} \mathrm{C}$ ) and then air dried. In the next step, $5 \mu \mathrm{L}$ TE buffer was added to each tube at $4{ }^{\circ} \mathrm{C}$ and left to dissolve for $1 \mathrm{~h}$, during which time the tubes were vortexed every $15 \mathrm{~min}$ for $10 \mathrm{~s}$. All DNA samples were stored at $-20^{\circ} \mathrm{C}$.

\subsection{DNA productivity calculation}

DNA productivity was calculated according to the method described by Wang et al. (2012). DNA (extracted with improved OSE and GLB) yield ( $\mu \mathrm{g}$ ) was quantified by the absorbance of light $(260 \mathrm{~nm})$ in a spectrophotometer (TU-1810) and calculated as: A260 $\times$ dilution factor $\times 50 \mathrm{ng} /$ $\mu \mathrm{L} / 1000 \times$ total sample volume in $\mu \mathrm{L}$. DNA yield per milligram shell (i.e., productivity; $\mu \mathrm{g} / \mathrm{mg}$ ) was calculated as: DNA yield/shell weight $(\mu \mathrm{g} / \mathrm{mg})$.

\subsection{Detection of target gene expression by PCR}

To ensure that the DNA from the shell was the same as the DNA from the soft body of the oyster. The shell DNA was used as a template. Fragments of the cytochrome $\mathrm{c}$ oxidase subunit I $(C O I)$ and $28 \mathrm{~S}$ ribosomal RNA (28S rRNA) genes were amplified, sequenced, and aligned with sequences in the nucleotide (Nt) database at the National Center for Biotechnology Information (NCBI; http://blast.ncbi.nlm.nih.gov/ Blast.cgi). PCR was performed in a volume of $25 \mu \mathrm{L}$ that contained $5 \times$ PCR buffer, $0.2 \mathrm{mM}$ deoxynucleotide triphosphate (dNTP), $2.5 \mathrm{mM} \mathrm{MgCl}_{2}, 0.5 \mathrm{U}$ Taq DNA polymerase, and $0.5 \mathrm{mM}$ of each primer (Tab. 1). PCR conditions were: $94^{\circ} \mathrm{C}$ for $10 \mathrm{~min}$ followed by 35 cycles of $94^{\circ} \mathrm{C}$ for $30 \mathrm{~s}, 55^{\circ} \mathrm{C}$ for $30 \mathrm{~s}, 72^{\circ} \mathrm{C}$ for $30 \mathrm{~s}$, and a final extension at $72^{\circ} \mathrm{C}$ for $7 \mathrm{~min}$. The PCR products were run on $1.2 \%$ agarose gel in $1 \times \mathrm{TAE}$ buffer to determine their molecular weight, and sequenced by Shanghai Sangon Biological Engineering Technology \& Services Co., Ltd., to obtain their nucleotide sequences. Ethidium bromide was the gel pre-cast. The primers used in the experiment are shown in Table 1.

The signal intensities of the PCR products were quantified with Image-Pro Plus image analysis software 6.0 (Media Cybernetics Inc., USA). Briefly, each captured image of a PCR gel was transformed to grayscale for subsequent single band quantification. The sampling procedure was performed in triplicate for each PCR band.

\subsection{Statistical analyses}

Image-Pro Plus 6 software was used to quantitatively analyze the gray levels of each PCR product. Statistical

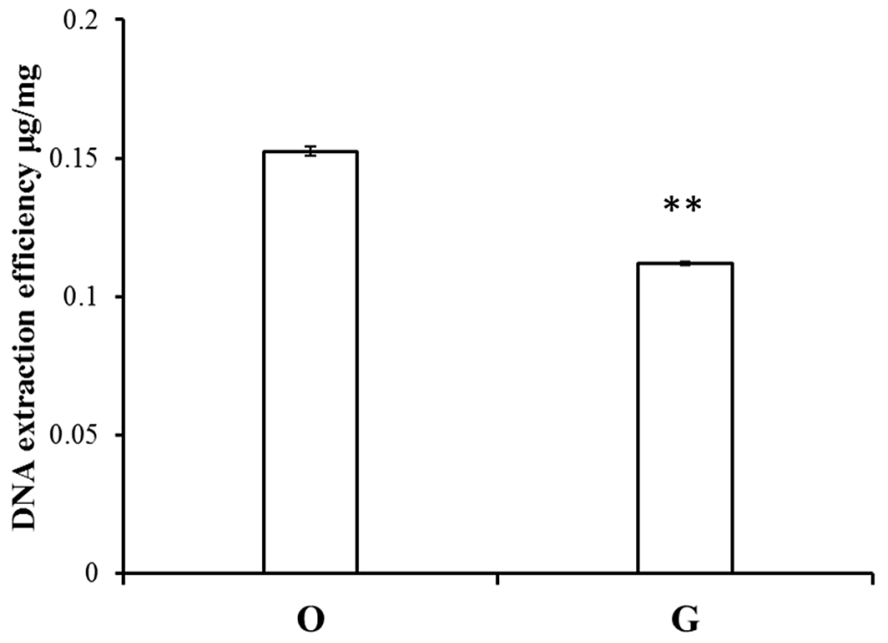

Fig. 2. The productivity of shell DNA extraction with the improved organic solvent extraction $(\mathrm{O})$ versus guanidine lysis buffer $(\mathrm{G})$ methods. Each bar represents the mean $\pm \mathrm{SD}(n=6)$. ${ }^{* *}(P<0.01)$.

analyses of the differences in DNA yield or gray levels were performed by paired $t$-test analysis using SPSS 16.0. $P$ values $<0.05$ were considered statistically significant.

\section{Results}

\subsection{Analysis of mortality}

After 30 days, all 20 oysters with part of their shell removed and all 20 oysters in the control group were alive. During the trial, no dead individuals were observed, indicating that sampling of the shell for DNA extraction did not harm the oysters.

\subsection{Comparison of the productivity of the shell DNA extraction methods}

The purity of the DNA extracted was expressed as the ratio of absorption at A260/A280. The average value of the oyster shell DNA extracted with OSE was $1.32 \pm 0.02$ (less than the standard value of 1.80). The concentration of DNA in the oyster shell was $3.05 \pm 0.03 \mu \mathrm{g} / \mu \mathrm{L}$, and the extraction productivity was $0.1525 \pm 0.0017 \mu \mathrm{g} / \mathrm{mg}$.

The A260/A280 of the oyster shell DNA extracted with GLB was $0.97 \pm 0.01$, which was lower than 1.80 , suggesting that there were impurities in the extracted shell DNA samples and that the purity of the DNA was low. The DNA concentration of the oyster shell extracted with GLB was $2.24 \pm 0.01 \mu \mathrm{g} / \mu \mathrm{L}$, and the extraction productivity was $0.1118 \pm 0.0007 \mu \mathrm{g} / \mathrm{mg}$, suggesting that the extraction efficiency was significantly lower than that of the improved OSE (Fig. 2, $P<0.01, n=6$ ).

The above results showed that shell DNA extracted with GLB contained more impurities and, thus, was less pure, than that extracted using OSE, which also showed higher DNA extraction efficiency. 

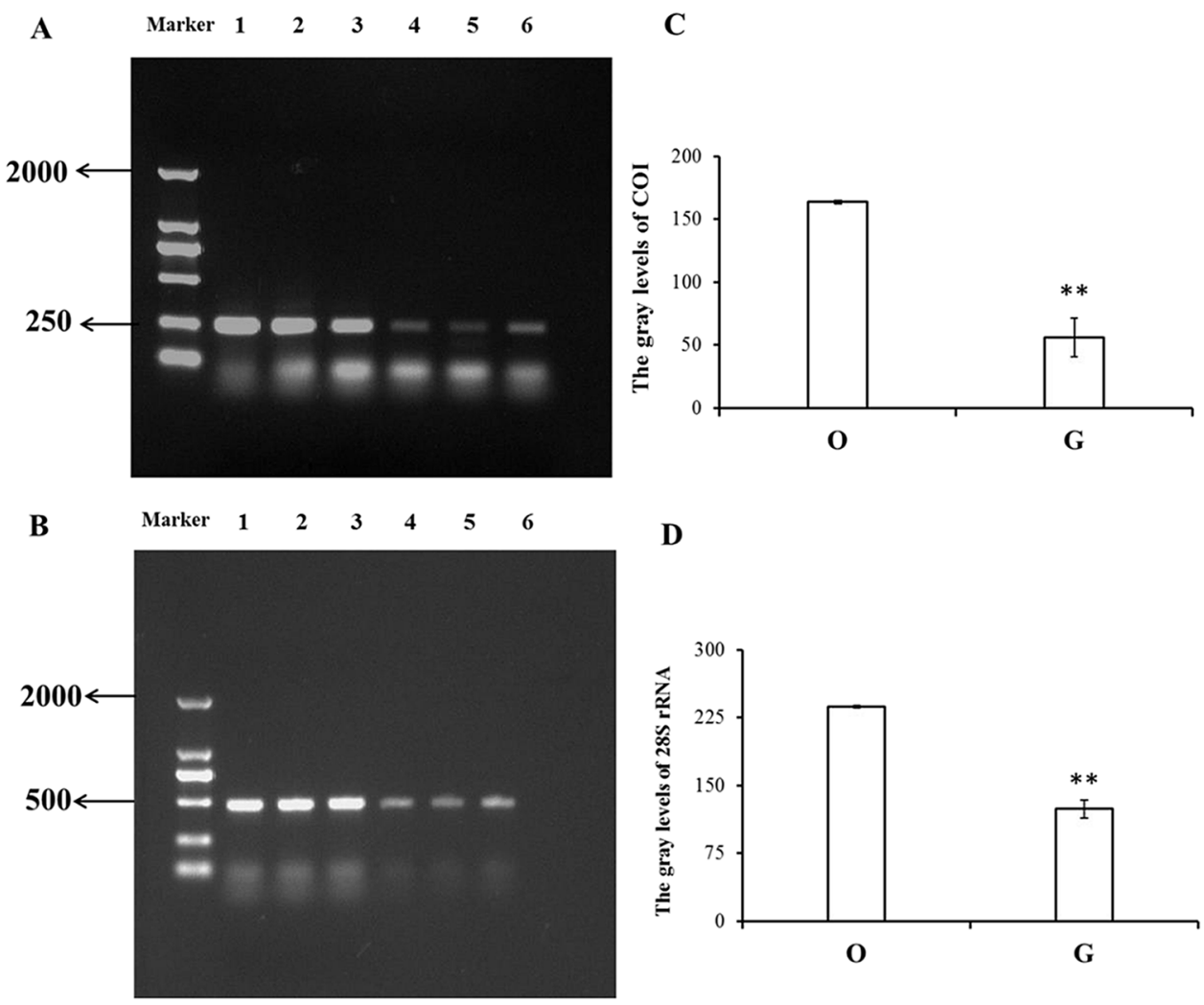

Fig. 3. Gel electrophoreses of PCR products and the gray values from COI and 28S rRNA DNA amplification using the OSE (O) and GLB (G) extraction methods. (A) Electrophoretic map of the COI target fragment, lanes 1-3 were shell DNAs extracted by improved OSE, and lanes 4-6 were shell DNAs extracted by GLB; (B) electrophoretic map of the 28S rRNA target fragment, lanes 1-3 were shell DNAs extracted by improved OSE, and lanes 4-6 were shell DNA extracted by GLB; (C) gray values of the target fragment of COI; and (D) gray values of the target fragment of $28 \mathrm{~S}$ rRNA. Each bar represents the mean $\pm \operatorname{SD}(n=3) .{ }^{* *} P<0.01$.

Table 2. Comparison of targeted DNA sequences from C. gigas shells.

\begin{tabular}{|c|c|c|c|}
\hline Accession & Description & $\begin{array}{l}\text { Max } \\
\text { score }\end{array}$ & $\begin{array}{l}\text { Total } \\
\text { score }\end{array}$ \\
\hline KY661508.1 & C. gigas isolate 010316 24C cytochrome c oxidase subunit I (COI) gene, partial cds; mitochondrial & 381 & 381 \\
\hline KY661505.1 & C. gigas isolate $010316 \_21 \mathrm{C}$ cytochrome c oxidase subunit I (COI) gene, partial cds; mitochondrial & 381 & 381 \\
\hline KY661502. & C. gigas isolate 010316 _ $06 \mathrm{AX}$ cytochrome c oxidase subunit I $(C O I)$ gene, partial cds; mitochondrial & 381 & 381 \\
\hline KY661501.1 & C. gigas isolate $010316_{-}^{-} 24 \mathrm{~F}$ cytochrome c oxidase subunit I (COI) gene, partial cds; mitochondrial & 381 & 381 \\
\hline AF137051.1 & C. gigas $28 \mathrm{~S}$ ribosomal RNA gene, partial sequence & 303 & 303 \\
\hline AB102757.1 & C. gigas genes for ITS2, 28S rRNA, partial sequence, country: Japan: Okinawa (Haneji inland sea) & 303 & 303 \\
\hline Z29546.1 & C. gigas gene for $28 \mathrm{~S}$ rRNA (partial) & 303 & 303 \\
\hline
\end{tabular}

\subsection{Validation of $\mathrm{COI}$ and 28S rRNA}

The DNA of the oyster shell was used as a template to validate the gene expression of $C O I$ and $28 \mathrm{~S}$ rRNA and to reveal whether shell DNA comes from the oyster genome. The subcellular locations of $C O I$ and $28 \mathrm{~S}$ rRNA are the mitochondria and nucleus, respectively.

PCR analysis showed that the bands corresponding to the gene fragments of COI (227 bp) and 28S rRNA (482 bp) were placed as expected, and were non-specifically amplified by electrophoresis (Fig. 3A,B), suggesting that the amplified $C O I$ and 28S rRNA from the genome and shell are matched the expected size of the target fragments from the oyster genome.

The separated DNA was sequenced after purification from the PCR gels and the nucleotide sequences of the amplified shell DNA segments of COI and 28S rRNA were aligned with the $\mathrm{Nt}$ database. The fragment size and BLAST results suggested that these two target genes belonged to $C$. gigas (Tab. 2). 


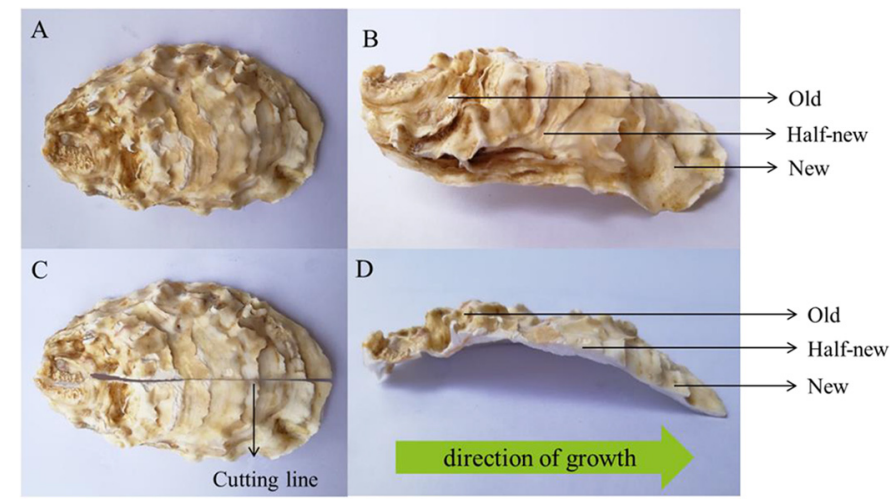

Fig. 4. The direction of shell growth. "Old" represents the earliest secreted shell. "New" represents the shell that has been secreted most recently. "Half-new" represents the shell produced between the earliest and most recent shell structures.

Analysis of the gray values of the electrophoretic strips for each target gene fragment was used to indicate the extraction efficiency of shell DNA. The gray values of COI and $28 \mathrm{~S}$ rRNA by improved OSE were significantly higher than those of GLB $(P<0.01)$, also suggesting that improved OSE had a higher DNA extraction efficiency than GLB (Fig. 3C,D).

The results of the PCR amplification and sequencing of the CDS region of $C O I$ were as follows:

CTCAAATAAGATGAGTACCTTAATAGATCAAGG GATAGTGCTAGTAAATGGCCCCCAACAGATCGCATA TTTCTAATCGTTACTATGAAATTAATTGACCTGAAA ATAGAGCTAATACCAGCAAGGTGAAGGCTTAGAAT TGCAAGGTCTATACAAACTCCATGATAAGAGTAAGT TGATAAAGGAGGGTAAATTGTTCACCCTGCCCCAAC TCCGTTTTCTA.

The results of the PCR amplification and sequencing of the CDS region of 28S rRNA were as follows:

GAGTAGGGTGCGAGAGCGGCCGGCCGGTCCTCG GTCTCGCGACGGCCCGCGTTCCGGAGGCTATAACTC CCAACCGGCGGAAACGAGTCCGCCGGCGGGCCACC TGCCTCCAGATCTTCTGACCGCCGATAGAAACCGGT CGTGGCGCTCGAGCCCGGAGAAAGTGCACACGTC GTCG.

\subsection{Comparison of DNA content in the ventral, middle, and dorsal edges of $C$. gigas shells}

The longitudinal distributions of the ventral (new), middle (half-new), and dorsal (old) edges of the oyster shell are shown in Figure 4D. The DNA in the different sampling regions was extracted by improved OSE; DNA content of the ventral, middle, and dorsal edges were $0.17 \pm 0.01 \mu \mathrm{g} / \mathrm{mg} \quad(n=6)$, $0.15 \pm 0.01 \mu \mathrm{g} / \mathrm{mg} \quad(n=6)$ and $0.14 \pm 0.02 \mu \mathrm{g} / \mathrm{mg} \quad(n=6)$, respectively. Statistical analysis showed that the DNA content of the ventral edge was significantly higher than that of the middle and dorsal edge $(P<0.05$, Fig. 5).

\section{Discussion}

Previous studies showed that the efficiencies of different DNA extraction methods vary significantly in extracting DNA

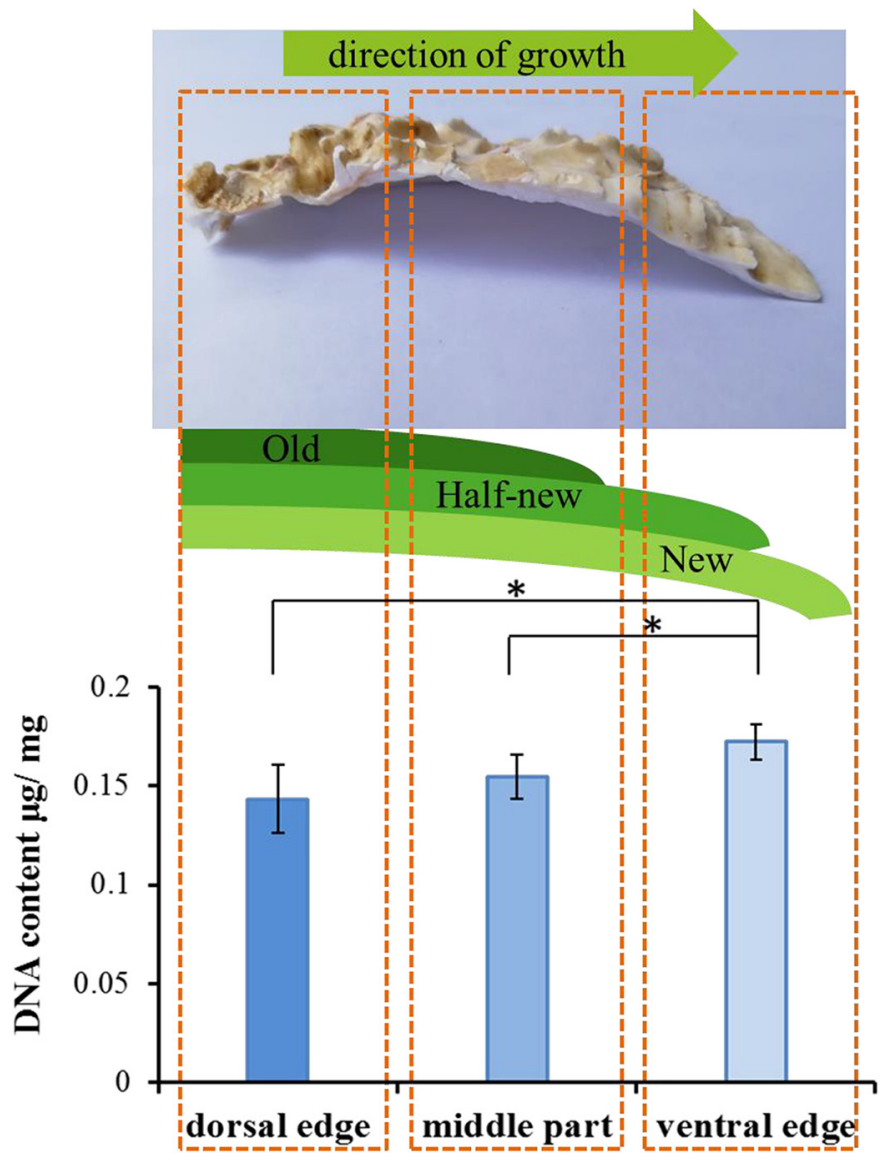

Fig. 5. Comparison of the DNA content in the ventral, middle, and dorsal edges of $C$. gigas shells. Each bar represented mean $\pm \mathrm{SD}$ $(n=6) . *(P<0.05)$. "Old" represents the earliest secreted shell. "New" represents the shell that has been secreted most recently. "Half-new" represents the shell produced between the earliest and most recent shell structures.

from calcareous shells. For example, GLB was more effective than other methods in extracting DNA from foraminiferan shells (Man et al., 2016). However, in the current study, an improved version of the OSE extraction method was more efficient for extracting DNA from C. gigas shells than was GLB. The OSE extraction method used in this study was based on a phenol-chloroform extraction method, with the primary modification of the addition of EDTA chelated $\mathrm{Ca}^{2+}$ to remove the calcium from $C$. gigas shells, thus enhancing the shell DNA extraction efficiency.

Previous studies of mollusk shell formation suggested that a class of granulocytic hemocytes may be directly involved in shell crystal production for oysters (Mount et al., 2004). These granulocytes may be directly involved in shell crystal production for oysters contain $\mathrm{CaCO}_{3}$ crystals, and they increase in abundance relative to other hemocytes following experimentally induced shell regeneration. The cells involved in shell-building might reside in the shell, and the mitochondrial and nuclear genomes contained in these cells are the probable origin of shell DNA (Li et al., 2004; Zhang et al., 2012). In this study, the target fragments of the mitochondrial gene $C O I$ and the nuclear gene $28 \mathrm{~S}$ rRNA were 
amplified using DNA extracted from the $C$. gigas shell as a template. After alignment and sequencing, the amplified target fragments were found to have originated from the mitochondrial and nuclear genomes of $C$. gigas, supporting the hypothesis that these cells are involved in shell formation. However, whether shell DNA has a direct effect on the process of shell formation is a focus for future research.

Comparison of the DNA contents of the dorsal, middle, and ventral edges of $C$. gigas shell showed that the DNA content was higher in the ventral edge than in the middle or dorsal edges, whereas the DNA content was the lowest in the dorsal edge. Previous studies reported that the shells of bivalves do not fall off during shell forming (Abele et al., 2009). It is known that the oldest section of the shell is the anterior umbo or "beak" of the oyster and the youngest or most recently formed section of shell is at the edge or "bill" of the oyster (Carriker, 1992; Suzuki and Nagasawa, 2013; Mcdougall and Degnan, 2018) which indicates that the dorsal edge is the earliest formed shell (old), the ventral edge is the newly formed shell, and the middle contains the "middle-aged" shell. Based on our observations and the DNA contents in the different parts of the shell, here, we propose a growth pattern of the oyster shell that we call a "Under Old \& Exceeding Old" shell growth pattern (Fig. 5). In this pattern, some of the new shell forms under the old shell (named "Under Old"); at the same time, other newly formed shell extended outwards from under the old shell toward the ventral edge of the shell ("Exceeding Old"). As a result, the dorsal edge of the shell is formed first, which could increase the possibility of DNA degradation. However, the ventral edge of the shell is newly formed, which could decrease the risk of DNA degradation. As a consequence, the DNA content is higher in the ventral edge than in other parts of the $C$. gigas shell. In addition, given that the ventral edge of $C$. gigas shells had the higher DNA content, this should be the preferred tissue for sampling for DNA extraction.

Molecular breeding has been successfully used in domesticated land-dwelling animals (Villanueva, 2005; Uemoto et al., 2011), partly because samples can be expediently acquired and prepared for DNA extraction and further molecular analysis without killing the animal. In contrast, $C$. gigas shells are difficult to open and sampling of the soft body of the oyster can result in high mortality rates, which is not conducive to the conservation and utilization of these oysters. Thus, the molecular breeding of mollusks is difficult on a large scale. In previous studies, oysters were soaked in a $\mathrm{MgSO}_{4}$ solution as anesthesia to open the shell; then, a small amount of the mantle tissue could be sampled for DNA extraction. However, this still resulted in a mortality rate $>16.7 \%$ for the operation (Wang et al., 2011). Therefore, our study has established an alternative, efficient, and safe approach for mollusk shell DNA extraction using only a small amount of shell DNA, which appears to contain genetic information relevant to the whole organism (i.e. the same as if the soft body had been sampled). Furthermore, the sampling method for the ventral edge of the shell used in this experiment did not result in the death of $C$. gigas, thus providing a reliable way for the molecular detection of individual genes and genotypes for use in mollusk molecular breeding.

\section{Conclusions}

In summary, this study proposes a more efficient method of obtaining $C$. gigas shell DNA by using an improved OSE method and sampling a patch of shell from the ventral edge. In addition, the $C$. gigas shell DNA was homologous to the C. gigas genome, laying a solid foundation for mortality-free genetic identification of these oyster, which will be particularly useful for the molecular breeding of these economically important organisms.

Acknowledgements. This research was supported by National Key R\&D Program of China (No. 2018YFD0901400), The National Natural Science Foundation of China (No. 41876193), The Key R \& D Program of Shandong Province, China (No. 2018GHY115027), The Shandong Provincial Natural Science Foundation, China (No. ZR2017BC058), A Project of Shandong Province Higher Educational Science and Technology Program (No. J17KA129), The Modern Agricultural Industry Technology System of Shandong Province, China (SDAIT-14-03), and The Key R \& D Program of Yantai City, China (No. 2017ZH054).

\section{References}

Abele D, Brey T, Philipp E. 2009. Bivalve models of aging and the determination of molluscan lifespans. Exp Gerontol 44: 307-315.

Carriker MR. 1992. Prismatic shell formation in continuously isolated (Mytilus edulis) and periodically exposed (Crassostrea virginica) extrapallial spaces - explicable by the same concept. Am Malacol Bull 9: 193-197.

Crenshaw MA. 1972. The soluble matrix from Mercenaria mercenaria shell. Biomineralisation 6: 6-11.

Currey JD. 1977. Mechanical properties of mother of pearl in tension. Proc R Soc Lond 196: 443-463.

Der Sarkissian C, Pichereau V, Dupont C, Ilsoe PC, Perrigault M, Butler P, Chauvaud L, Eiriksson J, Scourse J, Paillard C, Orlando L. 2017. Ancient DNA analysis identifies marine mollusc shells as new metagenomic archives of the past. Mol Ecol Resour 17: 835-853.

He G, Mai K. 1999. Biological macromolecules and molecular recognition in mollusk biomineralization. Prog Biochem Biophys 26: $310-312$.

Li S, Xie L, Zhang C, Zhang Y, Gu M, Zhang R. 2004. Cloning and expression of a pivotal calcium metabolism regulator: calmodulin involved in shell formation from pearl oyster (Pinctada fucata). Comp Biochem Physiol B 138: 235-243.

Lowenstam HA. 1981. Minerals formed by organism. Science 211: 1126-1131.

Man L, Lei YL, Tie-Gang LI. 2016. Efficiency of DNA preservation and extraction from benthic hyaline foraminifera of Ammonia SPP.: a methodological comparison. Oceanol Limnol Sin 346-353.

Mann S, Archibald DD, Didymus JM, Douglas T, Heywood BR, Meldrum FC, Reeves NJ. 1993. Crystallization at inorganicorganic interfaces: biominerals and biomimetic synthesis. Science 261: 1286-1292.

Mann S, Heywood BR, Rajam S, Wade VJ. 1991. Molecular Recognition in Biomineralization, Springer, Japan, 1993.

Mcdougall C, Degnan BM. 2018. The evolution of mollusc shells. Wiley Interdiscip Rev Dev Biol e313. 
Mount AS, Wheeler AP, Paradkar RP, Snider D. 2004. Hemocytemediated shell mineralization in the Eastern oyster. Science 304: 297-300.

Oberlander H. 1984. The invertebrate integument: biology of the integument. Science 226: 162-162.

Okumura K, Gennes PGD. 2001. Why is nacre strong? Elastic theory and fracture mechanics for biocomposites with stratified structures. Eur Phys J E 4: 121-127.

Pawlowski J. 2000. Introduction to the molecular systematics of Foraminifera. Micropaleontology 46: 1-12.

Samata T. Structure and Function of the Organic Matrix in the Nacreous Layer of Pinctada fucata, Springer, Japan, 1991.

Suquet M, de Kermoysan G, Araya RG, Queau I, Lebrun L, Le Souchu P, Mingant C. 2009. Anesthesia in Pacific oyster, Crassostrea gigas. Aquat Living Resour 22: 29-34.

Suzuki M, Nagasawa H. 2013. Mollusk shell structures and their formation mechanism. Can J Zool (Revue Canadienne de Zoologie) 91: 349-366.

Uemoto Y, Sato S, Ohtake T, Sato S, Okumura Y, Kobayashi E. 2011. Ornithine decarboxylase gene is a positional candidate gene affecting growth and carcass traits in $\mathrm{F}_{2}$ intercross chickens. Poult Sci 90: 35-41.
Villanueva B. 2005. Benefits from marker-assisted selection under an additive polygenic genetic model. J Anim Sci 83: $1747-1752$.

Wang X, Li L, Xu F, Zhang G. 2011. Genomic DNA extraction from in vivo sampled tissue of pacific oyster, Crassostrea gigas. Isr J Aquac - Bamidgeh 63: 1-3.

Wang X, Li L, Zhu Y, Du Y, Song X, Chen Y, Huang R, Que H, Fang X, Zhang G. 2013. Oyster shell proteins originate from multiple organs and their probable transport pathway to the shell formation front. PLoS One 8: e66522.

Wang X, Li L, Zhu Y, Song X, Fang X, Huang R, Que H, Zhang G. 2014. Aragonite shells are more ancient than calcite ones in bivalves: new evidence based on omics. Mol Biol Rep 41: 7067-7071.

Wang X, Song X, Li L, Zhang G. 2012. An improved method of DNA extraction from the shell of the Pacific oyster, Crassostrea gigas. Isr J Aquac - Bamidgeh 64: 1-4.

Weiner S, Hood L. 1975. Soluble protein of the organic matrix of mollusk shells: a potential template for shell formation. Science 190: 987-989.

Zhang G, Fang X, Guo X, Li L, Luo R, Xu F, Yang P, Zhang L, Wang X, Qi H. 2012. The oyster genome reveals stress adaptation and complexity of shell formation. Nature 490: 49-54.

Cite this article as: Jiang Q, Wei L, Gai C, Yu W, He C, Chen M, Zhang Z, Song H, Wang X, Wang X. 2019. An improved extraction method reveals varied DNA content in different parts of the shells of Pacific oysters. Aquat. Living Resour. 32: 5 